\title{
A casa ilhada
}

\section{MiLTON HATOUM}

Ra junho, auge da enchente, por isso tivemos que embarcar na beira do
igarapé do Poço Fundo e navegar até a casa no meio da ilhota.

Os moradores das palafitas olhavam-nos com surpresa, como se fôssemos turistas perdidos num lugar de Manaus que podia ser tudo, menos uma atração turística. No entanto, o cientista Lavedan, antes de voltar para Genebra, insistiu para que o acompanhasse até a casa ilhada, teimando em navegar num rio margeado de casebres miseráveis.

Nós nos encontramos no fim de uma manhã ensolarada lá no Bosque da Ciência, um dos raros recantos em que Manaus se concilia com a natureza. No Bosque os animais e peixes e plantas são conhecidos, e há sempre um cientista pronto para dissertar sobre pássaros, mariposas, orquídeas ou a arquitetura móvel dos cupins. Algumas árvores estão ali há cinco séculos, o aquário atrai como uma música das esferas, e os peixes, aprisionados, se tocam e se roçam e serpenteiam na água cristalina, tão diferente de sua morada original: o fundo de um lago ou rio de onde foram fisgados para sempre.

Eu estava diante do aquário, admirando um peixe pequeno e estranho à flor da água, quando uma voz estrangeira murmurou atrás de mim:

"É o tralhoto, um teleósteo da família..."

O homem parou de falar, tocou no vidro do aquário e acrescentou em voz alta: "Não importa a família, o que importa é o olhar desse peixe".

Então eu soube que o tralhoto, com seus olhos divididos, vê ao mesmo tempo o nosso mundo e o outro: o aquático, o submerso. dois..."

“Curioso", eu disse. "Ver o exterior já não é tão fácil, imagine ver os

"Por que você acha que estudo os peixes?”, interrompeu o estrangeiro, acariciando a placa de vidro. Os olhos de Lavedan encontraram os do tralhoto, e assim permaneceram, o peixe e o homem, quietos, encantados pelo magnetismo de tantos olhos voltados para dentro e para fora. Isso durou o tempo de um olhar demorado. Depois, Lavedan falou um pouco mais sobre esses teleósteos de olhar cindido, e de repente emudeceu. Parecia inquieto; em algum momento pareceu exasperado. Abriu a sacola de couro, apalpou-a por dentro, a mão direita trêmula sacou um cartão-postal. No rosto sério os lábios sumiram de sua boca, quem sabe um cacoete ou o gesto de um ansioso.

"Por favor, me acompanhe até esta casa", pediu ele, apontando a fotografia do cartão-postal. 
O tom da voz era quase de súplica; chegou a ser patético ao repetir o pedido em francês, e só não o fez em alemão porque dispensei mais salamaleques.

A casa ilhada... Eu a conhecia de vista: um bangalô atraente e misterioso, que só parece emitir sinal de vida ao anoitecer, quando as luzes iluminam a fachada e o jardim sem vida durante o dia. Sempre que atravessava a ponte sobre o igarapé, via uma ponta do telhado vermelho e imaginava a casa, o seu interior estranhamente habitado, como se alguma coisa lá dentro fosse proibida à cidade ou ao olhar alheio.

Agora o catraieiro remava lentamente, sempre no meio do igarapé, e Lavedan não se incomodou com o mal-cheiro que vinha das latrinas espalhadas nas margens, nem respondeu aos acenos e assobios das crianças que surgiam nas portas e janelas das palafitas. Aquele homem alto, careca, muito magro, rosto rosado, o corpo meio desajeitado na canoa, provocava risos, talvez galhofas. Ele tampouco deu bola para isso: mirava a fotografia da casa e o rio que se afunilava perto da ponte. Depois da curva do igarapé, avistamos o telhado vermelho sob o céu claro. No rosto de Lavedan surgiu um sorriso incompleto, talvez uma reação emotiva diante da casa que agora crescia com nitidez na parte mais elevada da ilhota.

O extenso gramado fora coberto pela enchente, poças de lama manchavam o jardim, mas os açaizeiros e os bancos de madeira caiados perto da varanda não tiravam o encanto do lugar. A copa de uma imensa sumaumeira cobria um pedaço do céu e dava magnitude ao lugar.

O catraieiro atracou ao lado de um barco abandonado, em cuja proa podia-se ler Terpsícore em letras vermelhas e desbotadas. Lavedan soletrou o nome do barco, saltou na lama, e, sem olhar para trás, caminhou em direção da casa. Entendi que devia esperá-lo na canoa.

Hoje, não saberia dizer quanto tempo ele demorou na casa. Mas a espera sob o sol abrasador multiplica os minutos, dilata o tempo. O catraieiro emprestou-me um chapéu de palha; depois assobiei, cantarolei, observei alguns detalhes da casa e do lugar; talvez tenha xingado o suíço misterioso, de quem só sabia o nome e as qualidades de ictiólogo contadas por ele mesmo. Meses depois conheceria algo do homem transtornado que ele foi ou que sempre será. No entanto, ao regressar da casa, Lavedan parecia sereno, reconfortado; murmurou palavras de agradecimento e pediu desculpas por ter ocupado uma parte da minha manhã. Disse que no meio da tarde viajaria para o Rio, de onde voaria para Zurique. Prometeu escrever-me "de algum lugar do outro hemisfério".

Isso aconteceu em 1996. Ou, para ser preciso: 16 de julho de 1996. Não me lembro do que me ocorreu há uma semana, mas se me lembro dessa data é porque no dia 18 de julho daquele ano os jornais de Manaus noticia- 


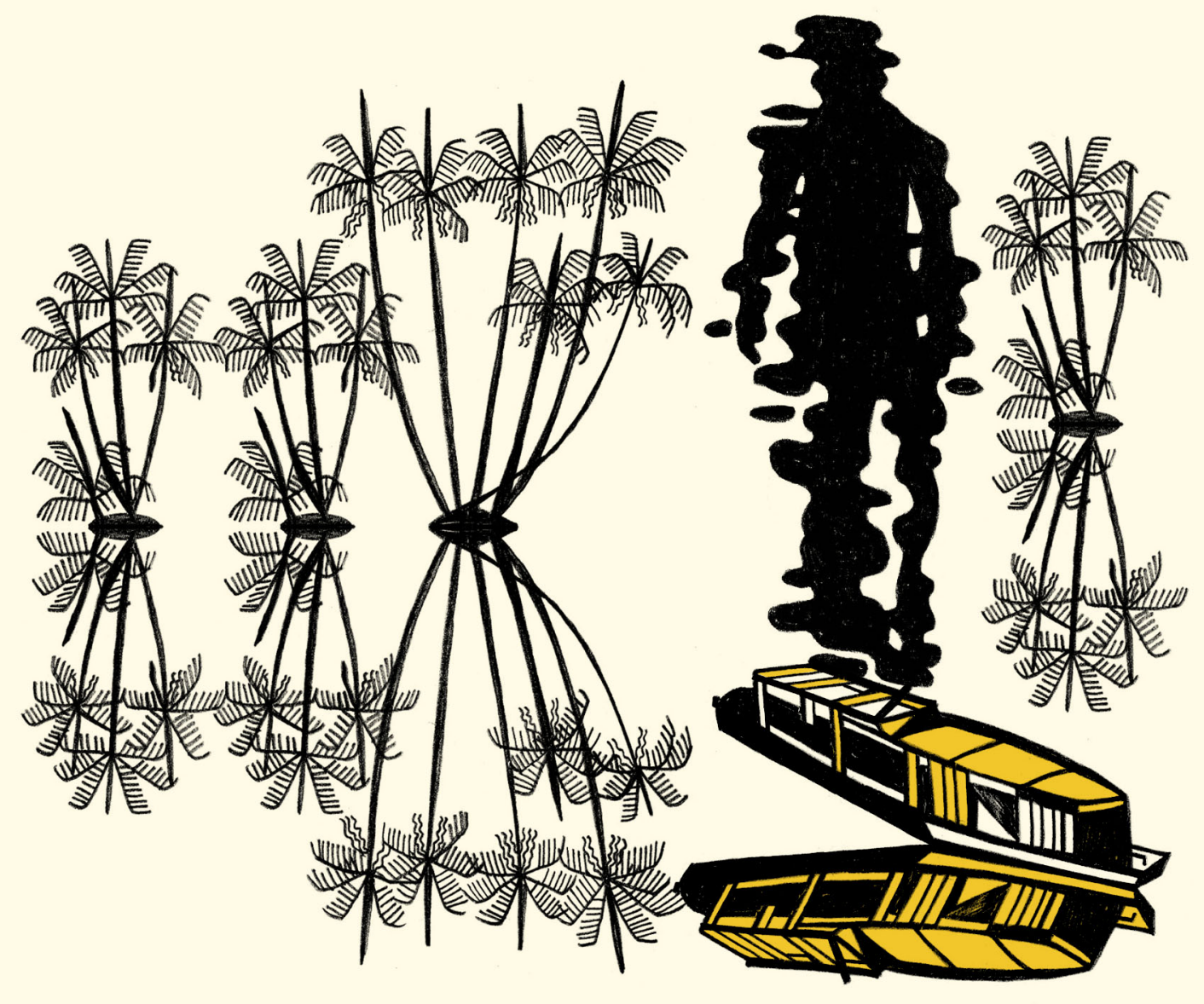

ram a morte do único morador da casa ilhada. O corpo, sem sinal de violência, fora encontrado na tarde do dia anterior. A fotografia da casa conduziume à notícia da morte. Encarei tudo isso como uma coincidência... Até que, dois meses depois, recebi uma carta de Lavedan.

Uma carta datilografada, em francês, postada em Londres. As primeiras linhas falam de seus estudos sobre peixes de água doce da faixa equatorial; dos peixes ele passou à paixão, e o resto da carta - ou seja, quase tudo refere-se a algo que talvez elucide nossa visita à casa ilhada.

Há uns vinte anos o jovem Lavedan e Harriet, sua esposa inglesa, fizeram uma viagem à Amazônia. Seria uma aventura, ou uma aventurosa lua-demel. O casal viajou de avião a Belém, e em seguida embarcaram no Caapara e conheceram dezenas de povoados à margem do Médio Amazonas. Doze dias depois, desembarcaram em Manaus. Estavam fartos de ver tanta água e floresta, fartos da solidão e do abandono dos ribeirinhos em lugares isolados, mas sedentos de festas e barulho, que uma cidade como Manaus tem de sobra. Não foi difícil o casal entrosar com uma turma de hedonistas manauaras. Fizeram amizades no Clube dos Ingleses, e, além do rock, dançaram ao 
ritmo de música caribenha, e cada um sentia o ardor de prazer nas narinas e na mente. Terminavam as noitadas no Mercado Municipal, onde comiam jaraqui frito e tomavam mingau de banana e mergulhavam nas águas do Negro a fim de aplacar a ressaca. Passaram mais de um mês em Manaus, imersos nessa magia noturna, e Genebra já era uma lembrança meio apagada, irreconciliável com a euforia do presente. Harriet e Lavedan chegaram a oferecer seus préstimos de jovens poliglotas às empresas alemãs e francesas da zona industrial de Manaus. Em algum momento pensaram em morar na cidade, mas essa conjectura foi interrompida bruscamente na madrugada de um dia que ele precisou na carta: 8 de março de 1978.

Dois dias depois, Daniel Lavedan voltou sozinho para a Europa.

Ele conta que deixou Manaus e a esposa por causa de um dançarino. Estavam numa festa do Shangri-Lá com a turma de notívagos intrépidos, e dançavam mambo e bolero numa atmosfera impregnada de álcool, suor e lança-perfume. O salão azulado do Shangri-Lá - uma maravilha, sublinhou Lavedan na carta - os envolvia, e eles trocavam de parceiro a cada música, e bebiam no gargalo o melhor uísque e se enrolavam de tanto rir e falar alto, embalados pelo brilho extático dos metais. No clímax dessa euforia, um homem altivo e sério demais atravessou o salão com passos meticulosos, aproximou-se da mesa dos notívagos, e, com um gesto reverente, pediu para dançar com Harriet. A cena causou risos: ninguém imaginava que aquele tipo, duro como um tronco de pau-ferro, fosse capaz de dar dois passos de uma valsa, quanto mais de um mambo. Para surpresa dos notívagos, ele dançou tão bem que a orquestra tocou só para ele. Para ele, e também para Harriet, que se deixou levar pelo rodopio daquele dervixe. Dançaram até o fim da noite, e, quando os metais e os batuques silenciaram, Lavedan entendeu que tudo estava acabado. Quer dizer, quase tudo, porque a lembrança de Harriet perdurava. Os três anos de namoro e os dois meses de vida amazônica tornaramse a lembrança atroz de uma única noite no Shangri-Lá.

Lavedan teve pesadelos com o par de dançarinos, e, às vezes, a figura garbosa e agora antipática, detestável do homem acercando-se da mesa o desviava de suas pesquisas sobre peixes. Nas viagens que fez à África e à Ásia a cena da dança o atormentava até mesmo durante o dia, como uma sucessão de pesadelos em plena vigília.

O tempo borra certas lembranças e pode mitigar o ódio, o ciúme, talvez a esperança. Quanto a isso, Lavedan concordava. Mas em Genebra, no inverno de 1980, ele recebeu a primeira notícia de Harriet: um cartão-postal com a imagem da casa ilhada; no verso, essas palavras em inglês: "O Shangri-Lá fechou, mas dançamos nessa pequena ilha: nossa morada".

A cada dois anos, ele recebia essa estranha notícia, até que em janeiro de 1996 ele abriu um envelope e encontrou um cartão-postal sem palavras. 
Lavedan deduziu desse silêncio uma possível fuga ou morte da mulher. "O resto dessa história você já sabe", escreveu ele, no fim da carta.

Conversei com alguns biólogos do Instituto de Pesquisas da Amazônia; um ictiólogo confirmou a relevância dos estudos de Lavedan. Sete peixes da faixa equatorial levam seu nome, mas ele nunca esteve na Amazônia, nunca publicou nada sobre a ictiologia dessa região.

Tampouco foram encontrados vestígios de homicídio no caso da casa ilhada. Desde então, a casa cercada de açaizeiros permanece fechada. E a carta de Lavedan ainda é, para mim, tão misteriosa como a identidade do estrangeiro. A carta, nosso encontro, a visita à casa ilhada...

Às vezes, de relance e a contragosto, me vêm à mente imagens daquele encontro: o rosto de Lavedan suado e vermelho, magnetizado pelo olhar do tralhoto; sua expressão de quase felicidade ao avistar a casa depois da curva do igarapé do Poço Fundo, a pesada sacola no ombro esquerdo, o salto impetuoso na lama e os passos resolutos em direção da casa, o brilho do suor na cabeça raspada, as mãos fechadas, o corpo alto e magro irrompendo na varanda e depois na sala, sem olhar para trás...

Milton Hatoum formou-se em arquitetura na FAU-USP e cursou mestrado em literatura comparada na Universidade de Paris III. Foi professor de literatura na Universiade Federal do Amazonas e na Universidade da Califôrnia (Berkeley). É autor dos romances Relato de um certo Oriente (1989) e Dois irmãos (2000), ambos publicados pela Companhia das Letras.

Ilustrações especialmente feitas por Andrés Sandoval.

Textos solicitados ao autor. Recebidos e aceitos para publicação em 10 de fevereiro de 2005 . 